УДК 168.522

\title{
Душенко Константин
}

\section{ОТ ВЕЛИКОГО ДО СМЕШНОГО}

Институт научной информации по общественным наукам РАН, Москва, Россия

Аннотащия. Выражение «От великого до смешного только один шаг» вошло в историю благодаря Наполеону, хотя возникло еще до него и восходит к «Диалогам мертвых» Б. де Фонтенеля. В статье рассматриваются свидетельства современников о беседе в Варшаве (декабрь 1812 г.), в которой Наполеон произнес эту фразу, и ее различные первоначальные варианты.

Ключевые слова: крылатые слова; Отечественная война 1812 г.; Наполеон I; Б. де Фонтенель; Д. де Прадт; Е. Тарле; М.И. Кутузов; А. Коцебу.

\section{Dushenko Konstantin \\ From the sublime to the ridiculous}

Institute of Scientific Information for Social Sciences

of the Russian Academy of Sciences

Abstract. The expression «From the sublime to the ridiculous is but a step» went down in history thanks to Napoleon, although it originated before him and goes back to the «Dialogues of the Dead» by B. de Fontenelle. 
The article examines the testimonies of contemporaries about a conversation in Warsaw (December 1812), in which Napoleon uttered this phrase and its various initial versions.

Keywords: origin of familiar phrases; The Patriotic War of 1812; Napoleon I; B. de Fontenelle; D. de Pradt; E. Tarle; M.I. Kutuzov; A. Kotzebue.

«От великого до смешного» - привычный, однако неточный перевод французского оборота «du sublime au ridicule». Впервые он появился в рассуждениях о литературных жанрах и стилях, поэтому вместо слова 'grand' (великое) используется 'sublime' - 'возвышенное', 'высокое', 'величественное'. Это различение соблюдается в иноязычных версиях: «from the sublime to the ridiculous» (англ.), «vom Erhabenen bis zum lächerlichen» (нем.), «dal sublime al ridicolo» (ит.), «od wzniosłości do śmieszności» (польск.). Как мы увидим ниже, в первом переводе на русский (1813) было то же самое: «от высокого до смешного». Форма «от великого до смешного» получила преобладание лишь во второй половине XIX в.

Добавим еще, что 'ridicule' означает не столько 'смешное' в смысле 'забавное', сколько 'достойное смеха', 'смехотворное', 'нелепое'.

Толстой в «Войне и мире» саркастически замечает: «"Du sublime (он что-то sublime видит в себе) au ridicule il n'y a qu'un pas", - говорит он. И весь мир 50 лет повторяет: sublime! Grand! Napoléon le grand!» («От величественного... до смешного только один шаг... Величественное! Великое! Наполеон Великий!», - авторский перевод) $[5$, c. 165$]$.

Эта фраза была произнесена Наполеоном при весьма печальных для него обстоятельствах. 5 декабря 1812 г. он оставил свою разгромленную армию и отправился в Париж в сопровождении генерала де Коленкура. 10 декабря император прибыл в Варшаву и остановился в Английской гостинице. Для решения вопроса о формировании добровольческого польского корпуса он вызвал к себе троих: французского посланника в Варшаве Доминика де Прадта, графа Станислава Потоцкого и Тадеуша Матушевича (министр финансов Герцогства Варшавского).

Их разговор - а вернее, длинный монолог Наполеона, изредка прерываемый репликами его собеседников, - приведен в книге Прадта «История посольства в Великое герцогство Варшавское» (1816). Бесе- 
да, скорее всего, была записана Прадтом в тот же день. Такова была дипломатическая практика, и так же записывал свои беседы с Наполеоном Коленкур. Сам Коленкур присутствовал при начале беседы, а потом слышал ее частично из соседней комнаты. Его записи в основных чертах совпадают с мемуарами Прадта.

Когда все собрались, Наполеон на какое-то время задумался, а после спросил: «Как долго я нахожусь в Варшаве?.. восемь дней... да нет, два часа, - со смехом поправил он себя. После чего произнес: От величественного до смешного только один шаг» (курсив здесь и далее мой. - К. Д.) $[13$, р. 214].

Польские собеседники императора сказали, что рады видеть его в добром здравии и вне опасности. «Опасность! ну что вы! - ответил Наполеон. - Я живу посреди волнений, для меня чем больше забот, тем лучше. Только бездельники короли жиреют у себя во дворцах; мое место на коне и в военном лагере. От величественного до смешного только один шаг» [13, р. 215].

Затем император, вопреки очевидности, стал уверять поляков, что все обстоит хорошо: «- Армия превосходна; у меня сто двадцать тысяч человек; я всегда побивал русских. Они не осмеливаются показываться перед нами. Это уже не те солдаты, что были при Фридланде и Эйлау» [там же]. Он долго и сбивчиво говорил, что полгода спустя, разбив русских у Одры, снова будет стоять на Немане; что всему виной климат; что противник ни на что не способен и во всех сражениях был побежден; что французские лошади не так выносливы, как русские; что, возможно, он слишком долго оставался в Москве. «Что ж! такова великая арена политики: кто ничем не рискует, ничего не получит. От величественного до смешного только один шаг» [13, p. 218].

Как видим, знаменитая фраза всякий раз появляется неожиданно и не очень-то к месту, перебивая ход разговора. В самом конце, сообщает Прадт, Наполеон повторил ее «еще дважды или трижды» [13, p. 219] - настолько прочно она застряла у него в голове.

Об этой беседе многие узнали еще до выхода в свет мемуаров Прадта - от польских собеседников императора. Е. Тарле в книге «Нашествие Наполеона на Россию» (1940) цитировал (в своем переводе с французского) некое письмо, отправленное из Варшавы. Здесь слова Наполеона переданы так: «Я покинул Париж в намерении не 160 
идти войной дальше польских границ. Обстоятельства увлекли меня. Может быть, я сделал ошибку, что дошел до Москвы, может быть, я плохо сделал, что слишком долго там оставался, но от великого до смешного - только один шаг, и пусть судит потомство» [4, с. 282].

Тарле счел это свидетельство совершенно достоверным, и слова Наполеона чаще всего цитируются у нас по его книге. Однако «письмо из Варшавы» никак нельзя считать надежным и независимым источником.

Оно взято из сборника Н.Ф. Дубровина «Отечественная война в письмах современников» (1882) [7]. Неизвестны ни его дата, ни отправитель, ни происхождение, ни местонахождение. Согласно этому письму, в беседе с Наполеоном участвовал генерал Тайи, военный комендант Варшавы, что опровергается записями Прадта и Коленкура. Но главное - это письмо почти целиком повторяет хорошо известный документ, опубликованный под названием «Речь к французскому посланнику и к польским министрам, произнесенная Наполеоном в Варшаве во время бегства его из России». Частично «Речь...» согласуется с записями Прадта и Коленкура, частично же им противоречит прежде всего там, где Наполеон рассыпается в похвалах польскому корпусу. Вероятно, ее источником были пересказы слов Наполеона, курсировавшие в Варшаве.

В марте 1813 г. «Речь...» появилась во французском эмигрантском журнале «L'Ambigu» [9]; в апреле, уже по-немецки, - в «Руссконемецком листке» (Берлин), а затем, в переводе с немецкого, в «Вестнике Европы».

Заметим, что в «Вестнике Европы» фраза Наполеона переведена: «Шаг от высокого до смешного очень мал» [3, с. 139]. (В «Руссконемецком листке»: «Vom Erhabenen bis zum lächerlichen...» [14, S. 67].) Именно в таком виде ее впервые узнал русский читатель.

В 1934 г. было опубликовано письмо графини Марии Терезы Тышкевич, отправленное князю Талейрану из Варшавы 20 декабря 1812 г. и перехваченное австрийцами. Речь Наполеона перед польскими министрами здесь близка к тексту, опубликованному журналом «L'Ambigu». Знаменитая фраза выглядит так: «Возможно, я совершил ошибку, войдя в Москву, и еще одну, оставаясь там слишком долго; потомство рассудит; смешное соседствует с возвышенным (le ridicule 
est à côté du sublime), так что в этом нет ничего удивительного» [8, p. 323].

Наконец, еще одну версию слов Наполеона привел, со слов графа Потоцкого, М.И. Кутузов: «"В сентябре я еще был повелителем мира, а теперь уже нет”, и, улыбнувшись, он [Наполеон] добавил: “так мало расстояние между величественным и смешным" (tant la distance est petite entre le sublime et le ridicule)» (письмо к жене из Плоцка от 2 (13) февраля 1813 г.; закавыченные слова Наполеона приведены пофранцузски) [1, с. 691]. Источник у Кутузова был вполне надежный, так что можно предположить, что Наполеон, повторяя фразу многократно, произнес ее и в таком виде.

16 марта 1818 г. граф Александр де Бальмен, наблюдавший за Наполеоном на о-ве Св. Елены в качестве российского комиссара, в своем донесении сообщал: «В Варшаве Бонапарт говорил: “От величественного до смешного только один шаг”. На Св. Елене он дважды в день повторяет: “От Капитолия до Тарпейской скальг только один шаг”» (в оригинале по-французски) [2, стб. 565, 673].

В здании Капитолия заседал римский сенат; Тарпейская скала часть Капитолийского холма, откуда сбрасывали преступников и изменников. Наполеон - или же Бальмен - несколько изменил изречение Октава Мирабо, одного из вождей Великой французской революции: «Невелико расстояние от Капитолия до Тарпейской скалы».

Благодаря Наполеону фраза «От великого до смешного...» вошла в историю. Однако она ему не принадлежит.

В 1683 г. вышли в свет «Диалоги мертвых древних и новейших лиц» Бернара де Фонтенеля. В одном из диалогов беседуют Сенека и французский поэт Поль Скаррон, автор комической поэмы «Вергилий наизнанку». Скаррон замечает: «...Ни одна вещь в мире не создана для серьезного к ней отношения. Я переложил в бурлескные стихи божественную “Энеиду” вашего Вергилия: нельзя было сделать ничего лучшего для того, чтобы показать, как близки между собой возвышенное и смешное! Они тесно расположены рядом» (пер. С. Шейнман-Топштейн, с заменой слова 'великое' на 'возвышенное') [6].

Эту мысль Скаррон поясняет примером, в котором при желании можно увидеть пророчество о судьбе Наполеона: «Все на свете напоминает перспективную живопись: разбросанные там и сям мазки об162 
разуют, например, если смотреть на картину с известной точки зрения, фигуру императора. Но измените точку зрения - и те же самые мазки представят вам оборванца» [6].

Мысль Фонтенеля не раз повторялась во французской и английской печати, а свою нынешнюю форму обрела во второй половине XVIII в. В 1777 г. в Амстердаме была напечатана - на французском языке - антология «Новые и философские мысли». Среди прочих изречений здесь, без указания автора, приведено следующее: «От великого до смешного, - говорит Фонтенель, один только шаг; от насмешки до оскорбления и того меньше (de la raillerie à l'insulte il y en a encore moins)» [12, p. 75].

Август Коцебу, опубликовавший «Речь...» Наполеона в своем «Русско-немецком листке», заметил: «Шаг от высокого до смешного не только очень мал, да еще и невозвратен» [3, с. 143]. То же самое говорит один из героев романа Лиона Фейхтвангера «Изгнание» (1939): «От великого до смешного один только шаг, но от смешного к великому пути уже нет» [10, s. 478].

Американский просветитель Томас Пейн считал иначе. Во 2-й части своего знаменитого трактата «Век разума», опубликованной в 1795 г., он писал: «Один лишний шаг, и возвышенное становится смешным; еще один лишний шаг, и смешное снова становится возвышенным» («... One step above the sublime, makes the ridiculous») [11, p. 563].

\section{Список литературы}

1. Голенищев-Кутузов М.И. Письма // Русская старина. - СПб., 1872. - Т. 5, № 5. C. $687-705$.

2. Из бумаг графа де Бальмена, русского пристава при первом Наполеоне, на острове Святой Елены // Русский архив. - М., 1870. - Т. 7. - Стб. 659-734.

3. Речь к французскому Посланнику и к Польским Министрам, произнесенная Наполеоном в Варшаве во время бегства его из России // Вестник Европы. - М., 1813. Ч. 69, № 9/10. - С. 139-143.

4. Тарле E.B. Нашествие Наполеона на Россию: 1812 год. - М.: Военное изд-во, 1992. $-303 \mathrm{c}$.

5. Толстой Л.Н. Полн. собр. соч.: В 90 т. - М.: Худож. лит., 1940. - Т. 12. - 426 с.

6. Фонтенель Б. де. Рассуждения о религии, природе и разуме. - М.: Мысль, 1979. - 304 с. - Режим доступа: https://unotices.com/page-books.php?id=67896 (Дата обращения: 1.12.2017.) 
7. Extrait d'une lettre de Varsovie // Дубровин Н.Ф. Отечественная война в письмах современников (1812-1815 гг.). - СПб.: Тип. Имп. акад. наук, 1882. - XXIV. - С. 577 677.

8. Dard E. Une lettre inedite de la Comtesse Tyskievitch adressee a Talleyrand // Revue d'histoire diplomatique. - Paris: A. Pedone, 1933. - P. 321-329.

9. Discours de l'Empereur (Napoléon) en passant par Varsovie, le 5 Décembre dernier, tenu en Présence de l'Ambassadeur de France et des Ministres Polonais // L'Ambigu: ou Variétés littéraires, et politiques. - Londres, 1813. - T. 40, N 359, 20 Mars. - P. 612.

10. Feuchtwanger L. Exil: Roman. - Berlin; Weimar: Aufbau-Verlag, 1964. - 502 S.

11. Knowles E. The Oxford Dictionary of Quotations. - Oxford: Oxford Univ. Press, 2001. $-1136 \mathrm{p}$.

12. Pensées nouvelles et philosophiques. - Amsterdam: Marc-Michel Rey, 1777.

13. Pradt D.-D. de. Histoire de l'ambassade dans Le Grand Duché de Varsovie en 1812. - Paris: Pillet, 1815. -239 p.

14. Rede Napoleons, gehalten auf seiner Durchreise durch Warschau, in Gegewart des französischen Gesandten und der polnischen Minister // Das russisch-deutsche Volksblatt. Berlin, 1813. - N 9, 20 April. - S. 66-68.

\section{References}

1. Golenishchev-Kutuzov M.I. Pis'ma // Russkaya starina. - SPb., 1872. - T. 5, № 5. S. $687-705$.

2. Iz bumag grafa de Bal'mena, russkogo pristava pri pervom Napoleone, na ostrove Svyatoj Eleny // Russkij arhiv. - M., 1870. - T. 7. - Stb. 659-734.

3. Rech' k francuzskomu Poslanniku i k Pol'skim Ministram, proiznesennaya Napoleonom v Varshave vo vremya begstva ego iz Rossii // Vestnik Evropy. - M., 1813. - Ch. 69, № 9/10. - S. 139-143.

4. Tarle E.V. Nashestvie Napoleona na Rossiyu: 1812 god. - M.: Voennoe izd-vo, 1992. $-303 \mathrm{~s}$.

5. Tolstoj L.N. Poln. sobr. soch.: V 90 t. - M.: Hudozh. lit., 1940. - T. 12. $-426 \mathrm{~s}$.

6. Fontenel' B. de. Rassuzhdeniya o religii, prirode i razume. - M.: Mysl', 1979.$304 \mathrm{s.} \quad$ Rezhim dostupa: https://unotices.com/page-books.php?id=67896 (Data obrashcheniya: 1.12.2017.)

7. Extrait d'une lettre de Varsovie // Dubrovin N.F. Otechestvennaya vojna v pis'mah sovremennikov (1812-1815 gg.) - SPb.: Tip. Imp. akad. nauk, 1882. - XXIV. - S. 577-677.

8. Dard E. Une lettre inedite de la Comtesse Tyskievitch adressee a Talleyrand // Revue d'histoire diplomatique. - Paris: A. Pedone, 1933. - P. 321-329.

9. Discours de l'Empereur (Napoléon) en passant par Varsovie, le 5 Décembre dernier, tenu en Présence de l'Ambassadeur de France et des Ministres Polonais // L'Ambigu: ou Variétés littéraires, et politiques. - Londres, 1813. - T. 40, N 359, 20 Mars. - P. 612.

10. Feuchtwanger L. Exil: Roman. - Berlin; Weimar, Aufbau-Verlag, 1964. - $502 \mathrm{~S}$.

11. Knowles E. The Oxford Dictionary of Quotations. - Oxford: Oxford Univ. Press, 2001. $-1136 \mathrm{p}$. 
12. Pensées nouvelles et philosophiques. - Amsterdam: Marc-Michel Rey, 1777.

13. Pradt D.-D. de. Histoire de l'ambassade dans Le Grand Duché de Varsovie en 1812. - Paris: Pillet, 1815. -239 p.

14. Rede Napoleons, gehalten auf seiner Durchreise durch Warschau, in Gegewart des französischen Gesandten und der polnischen Minister // Das russisch-deutsche Volksblatt. Berlin, 1813. - N 9, 20. April. - S. 66-68. 